\title{
THE FUTILE FOURTH AMENDMENT: UNDERSTANDING POLICE EXCESSIVE FORCE DOCTRINE THROUGH AN EMPIRICAL ASSESSMENT OF GRAHAM $V$. CONNOR
}

\author{
Osagie K. Obasogie \& Zachary Newman
}

\begin{abstract}
Graham v. Connor established the modern constitutional landscape for police excessive force claims. The Supreme Court not only refined an objective reasonableness test to describe the constitutional standard, but also held that the Fourth Amendment is the sole avenue for courts to adjudicate claims that police violated a person's constitutional rights in using force. In this Essay, we ask: What impact did this decision have on the nature of police excessive force claims in federal courts? To address this, we engaged in a qualitative examination of 500 federal cases (250 in the twenty-six years before Graham and 250 in the twenty-six years after) and coded for the types of claims brought by plaintiffs and recognized by federal courts. We find that prior to Graham, federal courts infrequently relied upon the Fourth Amendment in assessing police excessive force claims, a pattern that dramatically changed after the decision: only $28.0 \%$ of the pre-Graham cases include a discussion of the Fourth Amendment whereas $90.4 \%$ of the postGraham cases do. These findings suggest that the Supreme Court in Graham made a particular doctrinal choice in analyzing constitutional questions regarding police violence under the Fourth Amendment (which has an individualizing effect) instead of the Fourteenth Amendment's Equal Protection Clause and its potential to allow group-based and structural analysis - a move that did not reflect a preexisting trend or consensus in the federal courts. The Court's doctrinal choice in Graham has contributed to the perpetuation of police excessive use of force in many communities of color.
\end{abstract}

Authors - Osagie K. Obasogie, Haas Distinguished Chair and Professor of Bioethics, University of California, Berkeley, Joint 
Medical Program and School of Public Health. Zachary Newman, Visiting Scholar, University of California, Berkeley, Haas Institute for a Fair and Inclusive Society. Many thanks to Catherine Albiston, Khiara Bridges, and Tamara Lave for reviewing earlier drafts of this Essay.

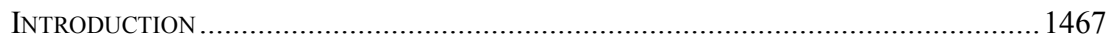

I. A Brief History of THE Individualizing Fourth AmENDMENT .................... 1470

A. The Bill of Rights Preserves and Prioritizes Individual Rights............... 1471

B. The Language and History of the Fourth Amendment Illustrate Its Individualized Focus...... 1472

C. Modern Criminal Procedure Doctrine Maintains the Individualized Focus of the Fourth Amendment...

II. Police Excessive Force: Supreme Court Case Law AND the Scholarly LITERATURE ............................................................................................ 1475

A. Key Cases on Police Use of Force: Garner to Graham ........................... 1475

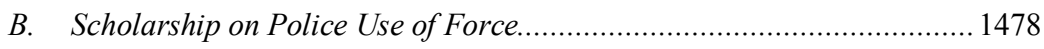

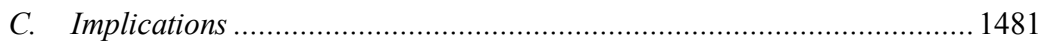

III. Qualitative Analysis of Pre- and Post-Graham Police Excessive

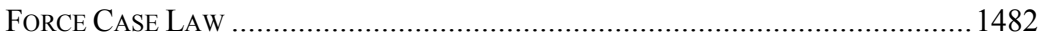

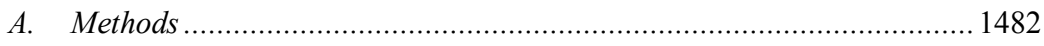

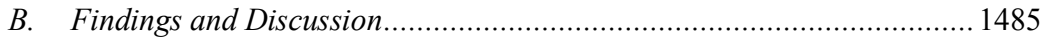

CONCLUSION: GRAHAM, MCCLESKEY, AND EQUAL ProteCTION............................... 1497 


\section{INTRODUCTION}

Recent social movements, such as Black Lives Matter, ${ }^{1}$ have forced racialized $^{2}$ police violence into public view. ${ }^{3}$ While an entrenched problem for communities of color, ${ }^{4}$ police officers' use of excessive force that maims and kills briefly became visible in the media and public discourse due to protest and public mourning. Nonetheless, the numbers remain staggering even after the massive outpouring of activism and discussion over the past few years. And the issue is not improving as time goes on. ${ }^{5}$

\footnotetext{
1 See, e.g., Alicia Garza, A Herstory of the \#BlackLivesMatter Movement by Alicia Garza, FEMINIST WIRE (Oct. 7, 2014), http://www.thefeministwire.com/2014/10/blacklivesmatter-2
} [https://perma.cc/E7ZU-QQSN].

2 See Center for Policing Equity, The Science of Justice: Race, Arrests, and Police Use OF FORCE 4 (2016) ("Even though this is a conservative estimate of bias, the analyses of 12 law enforcement departments from geographically and demographically diverse locations revealed that racial disparities in police use of force persist even when controlling for racial distribution of local arrest rates."); Justin M. Feldman et al., Quantifying Underreporting of Law-Enforcement-Related Deaths in United States Vital Statistics and News-Media-Based Data Sources: A Capture-Recapture Analysis, 14 PLOS MED. e1002449, 8-10 (2017) (finding that, in 2015, of a total of 1,086 cases, $27.1 \%$ of those killed by police were African-American, but only $13 \%$ of the U.S. population was African-American); see also Kimbriell Kelly et al., Fatal Shootings by Police Remain Relatively Unchanged After Two Years, WASH. POST (Dec. 30, 2016), https://www.washingtonpost.com/investigations/fatal-shootings-by-policeremain-relatively-unchanged-after-two-years/2016/12/30/fc807596-c3ca-11e6-9578-

0054287507db_story.html [https://perma.cc/5X2X-TPZ5] (“As was the case in 2015, a disproportionate number of those killed this year were black...."); John Sullivan et al., Number of Fatal Shootings by Police is Nearly Identical to Last Year, WASH. Post (July 1, 2017), https://www.washingtonpost.com/investigations/number-of-fatal-shootings-by-police-is-nearlyidentical-to-last-year/2017/07/01/98726cc6-5b5f-11e7-9fc6-c7ef4bc58d13 story.html

[https://perma.cc/4RWN-EHHK ] (“[P]olice have continued to shoot and kill a disproportionately large number of black males, who account for nearly a quarter of the deaths, yet are only 6 percent of the nation's population.").

${ }^{3}$ For an interesting discussion of the visibility of this issue over time, see FrANKLIN E. ZIMRING, WHEN POLICE KILL 3-11 (2017) ("The shooting of Michael Brown in August was followed by protests and pressure for criminal prosecution of the officer involved, and the angry visibility of the conflict in Ferguson, Missouri, generated sustained national attention. The months after the Ferguson episode saw local killings by police injected into a national conversation about police use of lethal force that was more sustained and intense than any before.").

${ }^{4}$ Nancy Krieger et al., Trends in US Deaths Due to Legal Intervention Among Black and White Men, Age 15-34 Years, by County Income Level: 1960-2010, 3 HARV. PUB. HeAlth ReV., Jan. 2015, at 2; George Yancy \& Judith Butler, What's Wrong With 'All Lives Matter'?, N.Y. TiMES: OPINIONATOR (Jan. 12, 2015, 9:00 PM), https://opinionator.blogs.nytimes.com/2015/01/12/whats-wrong-with-all-livesmatter [https://perma.cc/5U8G-BXUH] ("When we are ta[1]king about racism, and anti-black racism in the United States, we have to remember that under slavery black lives were considered only a fraction of a human life, so the prevailing way of valuing lives assumed that some lives mattered more, were more human, more worthy, more deserving of life and freedom, where freedom meant minimally the freedom to move and thrive without being subjected to coercive force. But when and where did black lives ever really get free of coercive force?").

5 In 2015, 995 people were killed, in 2016, 963, and in 2017, 987. 2015 Fatal Force Database, WASH. POST, https://www.washingtonpost.com/graphics/national/police-shootings [https://perma.cc/VZ2T-FUXF]; 2016 Fatal Force Database, WASH. POST, 
The data that have been recently collected, along with the history of police engagement with communities of color, highlight how the problem of excessive force is an iteration of the racial subordination that these communities experience across a host of social, political, and economic issues. For example, researchers at Boston University School of Public Health developed a structural racism index that took into account residential segregation, incarceration rates, educational attainment, economic indicators, and employment status and found that states with higher racial disparities in these areas also had greater Black/White disparities in fatal police shootings of unarmed victims. ${ }^{6}$ Thus, there is a link between the structural and environmental conditions that minorities experience and the ways in which these communities are policed. As Paul Butler notes in his book Chokehold: Policing Black Men, "what happens in places like Ferguson, Missouri, and Baltimore, Maryland-where the police routinely harass and discriminate against African Americans - is not a flaw in the criminal justice system. Ferguson and Baltimore are examples of how the system is supposed to work."

Yet, what is puzzling about the legal and public discourse on police violence is that it has largely been framed as a problem of individual "bad apples"-rogue officers who harbor animosity or fail to adhere to department regulations - or departmental shortcomings such as poor training or lack of clear policies. The primary narrative surrounding the issue of police excessive force appears to be one of differential legal and policy compliance: police enforce use of force policies and norms in a largely humane manner for Whites, and in more brutal ways for racial minorities. ${ }^{8}$

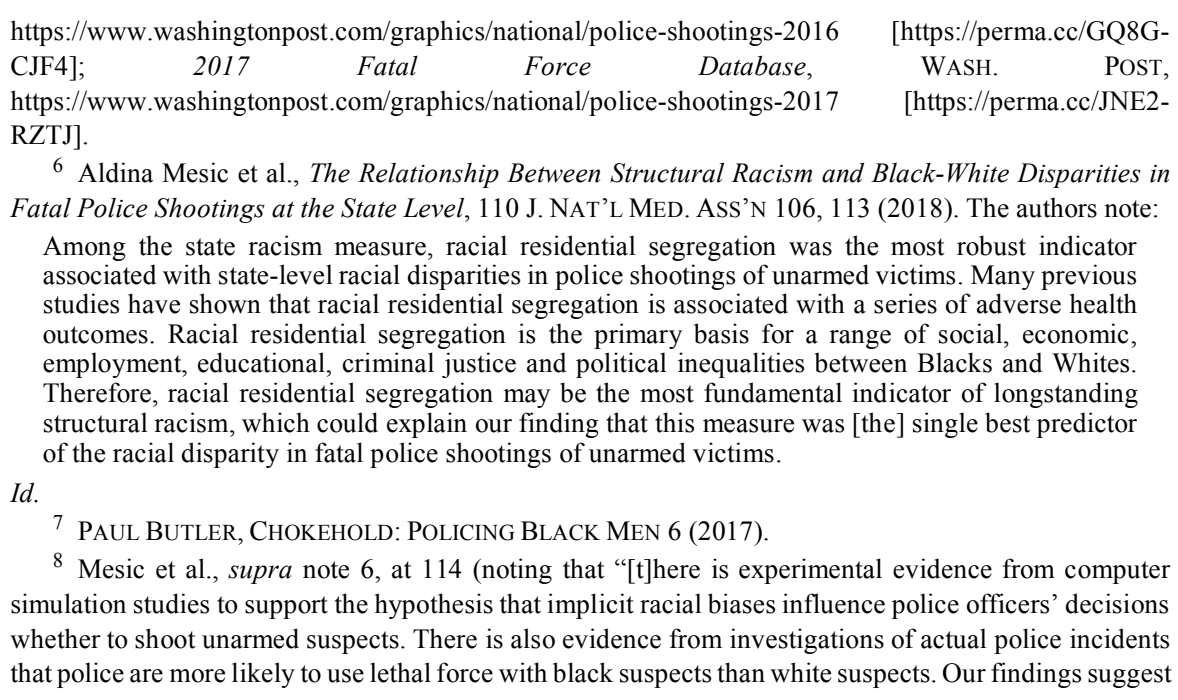

${ }^{8}$ Mesic et al., supra note 6, at 114 (noting that "[t]here is experimental evidence from computer simulation studies to support the hypothesis that implicit racial biases influence police officers' decisions whether to shoot unarmed suspects. There is also evidence from investigations of actual police incidents that police are more likely to use lethal force with black suspects than white suspects. Our findings suggest 
This understanding of police brutality treats issues of race, racism, and differential compliance as matters that exist outside of the (presumably) otherwise benign legal structures that shape how police operate. However, this construction fails to acknowledge how our constitutional structures channel the issue of police excessive force into particular legal terrains while signaling that other terrains are not viable. The prescriptive power of the Supreme Court has entrenched a knowledge and discourse around police violence that confines it solely to the territory of what we term the individualizing Fourth Amendment, ${ }^{9}$ which is a constitutional terrain that stands in opposition to acknowledging the pervasive racialized tensions between police and racial minorities that underlie many violent police interactions.

Specifically, through the pivotal police excessive force case of Graham $v$. Connor, the Court made a particular and consequential choice by funneling the diverse means by which federal courts had been adjudicating excessive force claims into one singular avenue. ${ }^{10}$ This holding dictated, as a matter of legal doctrine, that the constitutional standard for addressing all matters of police violence and excessive force is found solely in the Fourth Amendment, which frames the issue of excessive police force as one between the state and aggrieved individuals and eschews other relevant constitutional avenues such as the Fourteenth Amendment-an approach that has the potential to be more capable of dealing with group-based harms and structural forms of oppression. ${ }^{11}$ By individualizing police violence and scaling it down from a structural matter steeped in centuries of racial tensions to an individual dispute between officer and citizen, the Fourth Amendment has been used to depoliticize, deracialize, decontextualize, and ahistoricize a distinctive racial justice issue concerning the disproportionate use of force against people of color. This individualizing dynamic not only warps our

\footnotetext{
that the degree of racial bias among police officers in a state may be related to underlying levels of structural racism in that state").

9 "The right of the people to be secure in their persons, houses, papers, and effects, against unreasonable searches and seizures, shall not be violated, and no Warrants shall issue, but upon probable cause, supported by Oath or affirmation, and particularly describing the place to be searched, and the persons or things to be seized." U.S. CONST. amend. IV.

10490 U.S. 386, 388 (1989) ("This case requires us to decide what constitutional standard governs a free citizen's claim that law enforcement officials used excessive force in the course of making an arrest, investigatory stop, or other 'seizure' of his person. We hold that such claims are properly analyzed under the Fourth Amendment's 'objective reasonableness' standard, rather than under a substantive due process standard.").

11 Here, we emphasize the word "potential," as the Fourteenth Amendment, and equal protection in particular, currently has significant limitations that prevent it from being used in the liberating manner that we signal. This is discussed further in our Conclusion.
} 
understanding of the causes and consequences of police violence, but often leaves victims without any remedy.

With this Essay, we engage in an empirical examination of how Graham v. Connor led federal courts to have a reductionist understanding of police excessive force, and what this means for victims and plaintiffs. Part I briefly describes the history of the Fourth Amendment and how its individualist leanings were "baked in" by the Framers. Part II outlines both Supreme Court case law and the scholarly literature concerning police violence and use of force, which positions Graham as a transformative case that filters all matters pertaining to excessive police force through a Fourth Amendment lens. Part III discusses our original qualitative study of federal police violence cases pre- and post-Graham. This suggests that, with Graham, the Court effectively cordoned off other areas of constitutional law that have the potential to take structural dynamics into account (e.g., the Equal Protection Clause), yet nonetheless suffer from their own limitations. In our conclusion, we contend that Graham v. Connor, in combination with key equal protection cases of the era-namely, Washington v. Davis ${ }^{12}$ and McCleskey v. Kemp ${ }^{13}$ —reflects a broader ideological shift toward constitutional individualism when adjudicating matters dealing with race and racism. A more thoughtful engagement with social science methods and data across constitutional spaces dealing with racial disparities may lead to jurisprudential reconsiderations that can provide relief in the areas of police excessive force and beyond.

\section{A BRIEF HISTORY OF THE INDIVIDUALIZING FOURTH AMENDMENT}

This Part briefly argues that the Fourth Amendment is an area of constitutional law that is structurally unsuited to address racialized group harm - an evaluation that is necessary for understanding the nature of police violence today. This argument proceeds in three parts: (a) the Fourth Amendment is part of the Bill of Rights, which is a rights-granting framework largely based on the conception of singular individuals being provided singular rights; (b) the history and language of the Fourth Amendment both suggest a lack of structural awareness and a tuning to individual needs instead of group harm; and (c) the language and frameworks used in key criminal procedure cases decided during the modern era indicate that the Court continues to consider these issues - including police excessive force - as a matter solely between an individual citizen and a state actor.

\footnotetext{
12426 U.S. 229 (1976).

13481 U.S. 279 (1987).
} 


\section{A. The Bill of Rights Preserves and Prioritizes Individual Rights}

The Framers mirrored the Bill of Rights on British attempts to "prescribe the individual rights of the citizenry." 14 In essence, the Bill of Rights - based on common law, the Magna Carta, and other English law, as well as early colonial declarations discussing individual rights - provides citizens with individuated rights vis-à-vis the state. ${ }^{15}$ Certainly, the Bill of Rights is aware of some group concerns, such as the freedoms afforded religious groups under the First Amendment. Nevertheless, the overall structure of the Bill of Rights deals largely with distinctively individualized concerns and speaks to the particular dynamic between an individual and the federal government.

Consistent with these early sources, the Fourth Amendment epitomizes the individual-rights-focused nature of the Bill of Rights. Its inclusion as part of the Bill of Rights suggests that its provisions have an inherently limited scope, designed primarily to afford only atomized individuals-not groups-safeguards against federal power. $^{16}$ These individualized protections against the federal government were incorporated via the Fourteenth Amendment's Due Process Clause to also offer protections against state governments. ${ }^{17}$ In other terms, the Fourth Amendment, like the rest of the Bill of Rights, gives (in theory) "all" citizens individuated rights to be free from certain state conduct-i.e., a set of negative freedoms. ${ }^{18}$

\footnotetext{
14 Joyce A. McCray Pearson, The Federal and State Bills of Rights: A Historical Look at the Relationship Between America's Documents of Individual Freedom, 36 How. L.J. 43, 45 (1993).

15 Hon. GRegory M. CASKey, California SEARCh AND SeIZuRE $§ 1: 2$ (2017); see also 1 James BRYCE, THE AMERICAN COMMONWEALTH 357 (American ed. 1888) (stating that the "ten amendments made immediately after the adoption of the Constitution . . . constitute what the Americans, following the English precedent, call a Bill of Rights, securing the individual citizen and the States against the encroachments of Federal power"); McCray Pearson, supra note 14, at 49 (describing early charters and statutes in colonial America - such as Rhode Island's Charter (1663) or the Pennsylvania Charter of Privileges (1701) - enumerating rights and serving as the predecessors to a federal "Bill of Rights."). "The common thread in all of these documents is the borrowed idea of liberty from both sides of the Atlantic, creating a strong Anglo-American doctrinal concept of individual liberty." Id. (emphasis added).

16 Louise I. CAPEN \& D. MONTfort Melchior, My Worth to THE World: Studies in Citizenship 469 (1935) (“The first ten [amendments] — commonly called the Bill of Rights—guarantee certain rights to the individual."); see also Akhil Reed Amar, America's Lived Constitution, 120 YALE L.J. 1734, 1772 (2011) ("The Amendment affirmed a general right of Americans to be secure against unreasonable searches and seizures of 'their persons, houses, papers, and effects.' The word 'property' itself went unmentioned and was swept into the catchall category of all 'effects.' But intrusions upon individual bodies - 'persons' - raised special concerns. As with privacy more generally, bodies are distributed in egalitarian fashion; the rich man and the poor man alike each has one body, one 'person' entitled to special Fourth Amendment solicitude." (emphasis added)).

17 In the Fourth Amendment context, see Mapp v. Ohio, 367 U.S. 643 (1961).

18 Ronald J. Bacigal, Putting the People Back into the Fourth Amendment, 62 GEO. WASH. L. REV. 359, 360 (1994) ("“M]uch of the amendment's jurisprudence centers on the courts' efforts to regulate law enforcement activity that intrudes upon protected rights of privacy and liberty."); see, e.g., Olmstead v.
} 


\section{B. The Language and History of the Fourth Amendment Illustrate Its Individualized Focus}

As a second point, the language and history of the Fourth Amendment points to an individualized right as well. The Amendment provides:

The right of the people to be secure in their persons, houses, papers, and effects, against unreasonable searches and seizures, shall not be violated, and no Warrants shall issue, but upon probable cause, supported by Oath or affirmation, and particularly describing the place to be searched, and the persons or things to be seized. ${ }^{19}$

The Fourth Amendment thus guarantees a generalized right held by everyone (i.e., "the people") to individually be free from unreasonable searches and seizures in their singular "persons" and their singular private properties (e.g., "houses, papers, and effects"). ${ }^{20}$ Moreover, the Amendment arose, at least in part, as a response to certain searches and seizures practiced in colonial America, namely the "writ of assistance." 21 This history suggests that the Fourth Amendment evolved out of a particular desire to stop government searches and seizures of persons and property conducted without a warrant or probable cause..$^{22}$ Thus, both the language of the Fourth Amendment and its underlying historical rationale suggest that its protections extend to an individual seeking legal shelter from undue governmental searches and seizures.

\section{Modern Criminal Procedure Doctrine Maintains the Individualized Focus of the Fourth Amendment}

Lastly, even when expanding rights in the criminal procedure realm, the Supreme Court has not deviated from this individualized framework in the

\footnotetext{
United States, 277 U.S. 438, 478 (1928) (Brandeis, J., dissenting) (classically framing it as the "right to be let alone").

19 U.S. CONST. amend. IV.

20 Akhil Reed Amar, The Bill of Rights as a Constitution, 100 YALE L.J. 1131, 1177 (1991) ("Even more important, in the Fourth Amendment, as nowhere else in the Constitution, the collective-sounding phrase 'the people' is immediately qualified by the use and subsequent repetition of the more individualistic language of 'persons."').

211 Wayne R. LAFAVE, SEARCh AND SEIZURE: A TREATiSe ON THE Fourth AMENDMENT § 1.1(a) (5th ed. 2012) ("The writ of assistance, seldom used in England, was utilized by customs officers to enter and search buildings for smuggled goods."); Bacigal, supra note 18 at 364; George C. Thomas III, Stumbling Toward History: The Framers' Search and Seizure World, 43 TEX. TECH L. REV. 199, 206 (2010) ("The history is clear that the colonists were hostile to British searches under the infamous writs of assistance. These searches required neither a warrant nor probable cause.").

22 See, e.g., Olmstead, 277 U.S. at 463 (majority opinion) ("The well known historical purpose of the Fourth Amendment, directed against general warrants and writs of assistance, was to prevent the use of governmental force to search a man's house, his person, his papers and his effects; and to prevent their seizure against his will."); Thomas, supra note 21, at 206.
} 
context of search and seizure. Specifically, during the mid-century Warren Court era, when the Court stimulated a then-new constitutional discourse on police activity, ${ }^{23}$ particularly regarding searching ${ }^{24}$ and seizing ${ }^{25}$ individual citizens, the constitutional discourse remained focused on cognizing Fourth Amendment protections as individuated. Put differently, even as the Fourth Amendment paradigm became one in which "courts use the Constitution as the primary means of regulating the police," the scope remained fixed on the individual person who had her rights violated and could bring an individuated claim for that violation. ${ }^{26}$ Hence, while the Court expanded rights and remedies, it did not disrupt the overarching and inherent narrative of the individualized Fourth Amendment schema. These cases limited alternative means of addressing the group-based harm that fundamentally characterizes racialized police violence by ensuring that isolated criminal cases and civil suits are the only means to seek remedies. ${ }^{27}$

It is clear from these cases that the Fourth Amendment exists within an individualizing constitutional terrain that focuses primarily on whether a given search or seizure is a reasonable intrusion against the privacy interests of an individual, whether it be her person, her home, or her items. ${ }^{28}$ The

23 Rachel A. Harmon, The Problem of Policing, 110 MICH. L. REV. 761, 765 (2012) ("By expanding constitutional rights, the Court brought constitutional law to bear directly on police officers and departments. By augmenting constitutional remedies, the Court facilitated court challenges to police conduct. And by justifying its sweeping action on the ground that local and state governments had failed to prevent police misconduct, the Court established the primacy of constitutional adjudication for regulating the police.").

24 See Mapp v. Ohio, 367 U.S. 643, 660 (1961) ("Our decision, founded on reason and truth, gives to the individual no more than that which the Constitution guarantees him, to the police officer no less than that to which honest law enforcement is entitled, and, to the courts, that judicial integrity so necessary in the true administration of justice." (emphasis added)).

25 See Terry v. Ohio, 392 U.S. 1, 9 (1968) ("No right is held more sacred, or is more carefully guarded, by the common law, than the right of every individual to the possession and control of his own person, free from all restraint or interference of others, unless by clear and unquestionable authority of law.” (quoting Union Pac. R. Co. v. Botsford, 141 U.S. 250, 251 (1891) (emphasis added)).

26 Harmon, supra note 23, at 765.

27 Id. at 765-67; Dan M. Kahan \& Tracey L. Meares, The Coming Crisis of Criminal Procedure, 86 GEO. L.J. 1153, 1157-58 (1998) ("Rather than meet racism head on, the Court began to fight it indirectly through general constitutional standards that did not explicitly address race but that were nonetheless calculated to constrain racially motivated policies.").

28 Thomas K. Clancy, The Fourth Amendment as a Collective Right, 43 TEX. TECH L. REV. 255,256 (2010) ("For most of the history of the United States, the view that the Fourth Amendment served to protect individual security - that it was an individual right - was so patently obvious that it needed no support."); Arnold H. Loewy, The Fourth Amendment: History, Purpose, and Remedies, 43 TEX. TECH L. REV. 1, 5 (2010) ("[I]n case after case, the Court has emphasized that the overarching principle of the Fourth Amendment is reasonableness."); see also Graham v. Connor, 490 U.S. 386, 395 (1989) (stating that "the Fourth Amendment provides an explicit textual source of constitutional protection against ... physically intrusive governmental conduct" and therefore is the proper constitutional site for police violence cases); Laura K. Donohue, The Original Fourth Amendment, 83 U. CHI. L. REV. 1181, 1276 
Amendment deals with the relationship between an individual citizen and the state, delimiting the power of the state-via the police - to invade that person's privacy through a search or seizure, requiring protections like individualized suspicion and particularity in warrants that specify who the individual is that the state is acting upon. ${ }^{29}$ It concerns a one-to-one dynamic between the state and a citizen that limits the matter solely to the protection and constitutional articulation of that singular citizen's individualized rights and remedies. ${ }^{30}$ This individualized understanding of the Fourth Amendment, and its associated limitations, has been mapped onto police violence cases concerning use of force. Excessive force analyses now exist exclusively in the domain of the Fourth Amendment and, as a result, the individualized relationship between the harmed civilian and the rightsviolating state. According to this framework, deadly force constitutes a seizure for Fourth Amendment purposes and is therefore "subject to the reasonableness requirement of the Fourth Amendment." ${ }^{31}$

Consequently, Fourth Amendment jurisprudence, particularly as it relates to excessive force claims, presents a discursive and doctrinal limitation that constrains the issue of police use of excessive force solely to individual rights that are abridged by unwarranted state intervention. Due to this limitation, as an individualized constitutional doctrine, the Fourth Amendment is simply not designed to address the group inequalities and racial dynamics that characterize police violence today.

(2016) ("The right to be protected within one's home included the right not to be subject to promiscuous search and seizure. The government thus could not, at will, search an individual's 'person, his houses, his papers, and all his possessions."').

${ }^{29}$ M. Blane Michael, Reading the Fourth Amendment: Guidance from the Mischief that Gave It Birth, 85 N.Y.U. L. REV. 905, 921-22 (2010) (“The Fourth Amendment was thus adopted for the purpose of checking discretionary police authority, and that historical purpose should be kept in mind.").

30 See Clancy, supra note 28, at 255 ("[T]he Amendment has been traditionally interpreted to safeguard the rights of individuals in atomistic spheres of interests ...." (emphasis added)); Tracey Maclin, The Central Meaning of the Fourth Amendment, 35 WM. \& MARY L. REV. 197, 198-99 (1993) ("Whether a particular search or seizure is reasonable is generally determined by balancing the competing interests at stake - the government's interest in effective law enforcement versus the individual's interest in privacy and personal security."); Robert Weisberg, Foreword: A New Agenda for Criminal Procedure, 2 BUFF. CRIM. L. REV 367, 368 (1999) ("[C]riminal procedure addresses a distinct and fundamental political conflict at the heart of American constitutionalism - the condemnatory and physical power of state versus the individual.").

31 Tennessee v. Garner, 471 U.S. 1, 7 (1985). 


\section{Police EXCESSIVE ForCE: SuPREME COURT CASE LAW AND THE SCHOLARLY LITERATURE}

Prior to the Supreme Court's holding in Graham v. Connor, ${ }^{32}$ federal courts used a variety of legal mechanisms to assess claims that a particular use of force by the police violated the Constitution. In Graham, the Supreme Court brought uniformity to this area of law by stating that all excessive force claims should be analyzed through the Fourth Amendment. ${ }^{33}$ In line with this doctrinal shift, post-Graham legal scholarship discussing police violence and constitutional law also reflects this emphasis. ${ }^{34}$ As a result, what we have is federal courts engaging in a hyper-focus on the Fourth Amendment postGraham, and scholars not fully exploring the fact that it has not always been this way or the implications of this particular doctrinal choice. ${ }^{35}$ This Part illustrates these developments by (a) describing the jurisprudential strategies prior to the Court's decision in Graham, (b) surveying the relevant scholarship evaluating these cases, and (c) briefly noting the implications of these gaps in the conversations.

\section{A. Key Cases on Police Use of Force: Garner to Graham}

Tennessee v. Garner ${ }^{36}$ and Graham v. Connor ${ }^{37}$ represent the two foundational cases in this area. In Garner, the Court held:

[I]f the suspect threatens the officer with a weapon or there is probable cause to believe that he has committed a crime involving the infliction or threatened

\footnotetext{
32490 U.S. at 388 ("This case requires us to decide what constitutional standard governs a free citizen's claim that law enforcement officials used excessive force in the course of making an arrest, investigatory stop, or other 'seizure' of his person. We hold that such claims are properly analyzed under the Fourth Amendment's 'objective reasonableness' standard, rather than under a substantive due process standard.").

33 See Part III for our qualitative findings.

34 See infra Section II.B.

35 In addition, the Court rarely discusses police violence. See John P. Gross, Judge, Jury, and Executioner: The Excessive Use of Deadly Force by Police Officers, 21 TEX. J. ON CIV. LIBERTIES \& CIV. RTS. 155, 157 (2016) ("The United States Supreme Court seldom addresses the issue of police officer use of force; when the issue is addressed, legal justifications for the use of force, and the limitations on when the use of force is appropriate are not analyzed or discussed in any great detail."). Furthermore, the lack of scholarly engagement may be because the Court so clearly established that there is no place for the Fourteenth Amendment in police excessive force analyses, because scholars do not believe that the Fourteenth Amendment has a role in these cases, or because they do not see police killings as a pressing social problem. See ZIMRING, supra note 3, at 8-9 ("The published record of legal journals provides another indication of the low visibility of police killings as a focus of critical concern and scholarly activity.").

36471 U.S. 1.

37490 U.S. 386.
} 
infliction of serious physical harm, deadly force may be used if necessary to prevent escape, and if, where feasible, some warning has been given. ${ }^{38}$

By saying that police could not use deadly force unless the person posed a threat of death or physical injury, the Court clearly stated that deadly force should not be used against a fleeing, unarmed person. ${ }^{39}$

Garner is praised by critics of the Court's subsequent Fourth Amendment jurisprudence as a case that actually created a bright-line rule designed to regulate fatal force. ${ }^{40}$ However, Garner, via Justice Sandra Day O'Connor's dissent, also signaled a more limited future trajectory for how the Court would regard the problem of police violence. O'Connor's dissent set the stage for what was to come for police violence jurisprudence. ${ }^{41}$ In her dissent, O'Connor began to sketch a different reasonableness standard: "[T] he reasonableness of Officer Hymon's conduct for purposes of the Fourth Amendment cannot be evaluated by what later appears to have been a preferable course of police action." ${ }^{\prime 2}$ O'Connor contended that the Fourth Amendment does not prohibit an officer from using deadly force in such a scenario, in contrast to the majority. ${ }^{43}$

The Graham Court used this Fourth Amendment philosophy articulated in Justice O'Connor's dissent to push police excessive force doctrine in a more restricted direction that focused solely on a reasonableness standard rather than bright-line rules that actually restrict police use of force. Yet, the Court did not explicitly overrule Garner. ${ }^{44}$ The Graham case arose when

38471 U.S. at 11-12; see ZIMRING, supra note 3, at 19 ("As a matter of constitutional principle, the Garner case was a decisive rejection of generalized law enforcement authority to use force as also a justification for killings by police ....”).

39 Garner, 471 U.S. at 3, 11 ("The use of deadly force to prevent the escape of all felony suspects, whatever the circumstances, is constitutionally unreasonable. It is not better that all felony suspects die than that they escape. Where the suspect poses no immediate threat to the officer and no threat to others, the harm resulting from failing to apprehend him does not justify the use of deadly force to do so.").

40 Brandon Garrett \& Seth Stoughton, A Tactical Fourth Amendment, 103 VA. L. REV. 211, 216 (2017) (calling Garner "a high-water mark" for police violence case law); Nancy C. Marcus, From Edward to Eric Garner and Beyond: The Importance of Constitutional Limitations on Lethal Use of Force in Police Reform, 12 DuKe J. Const. L. \& PuB. PoL'y 53, 80, 82 (2016).

41 Garner, 471 U.S. at 29 (O’Connor, J., dissenting); Garrett \& Stoughton, supra note 40, at 217 (describing how the flexible "totality of the circumstances" standard, including the discussion of "splitsecond" decisions from Graham, "originat[ed] in Justice Sandra Day O'Conn[o]r's dissent in Garner, [and] has animated the Court's excessive-force case law ever since").

42 Garner, 471 U.S. at 29 (O'Connor, J., dissenting).

43 Id. at 23 ("By disregarding the serious and dangerous nature of residential burglaries and the longstanding practice of many States, the Court effectively creates a Fourth Amendment right allowing a burglary suspect to flee unimpeded from a police officer who has probable cause to arrest, who has ordered the suspect to halt, and who has no means short of firing his weapon to prevent escape. I do not believe that the Fourth Amendment supports such a right, and I accordingly dissent.").

44 Marcus, supra note 40, at 82-83 (describing the progression of police violence case law from Garner through Scott v. Harris in 2007 as never actually abrogating or overruling Garner). 
Dethorne Graham - an African-American man and diabetic - attempted to get orange juice from a convenience store when a cop "became suspicious" because he saw Graham enter and leave the store quickly. ${ }^{45}$ The officer cuffed Graham and continuously failed to respond to the fact that Graham was having an insulin reaction; Graham sustained multiple injuries during the encounter. ${ }^{46}$ Graham filed suit under 42 U.S.C. $§ 1983$, alleging that the police had used excessive force against him in violation of the Fourteenth Amendment. ${ }^{47}$ The district court found for the police, applying a four-factor test from Johnson v. Glick. ${ }^{48}$ The court of appeals affirmed the lower court ruling, with Graham arguing that it was error to require that excessive force must be "applied maliciously and sadistically to cause harm" in order to have a successful claim. ${ }^{49}$

The Supreme Court held that excessive force "claims are properly analyzed under the Fourth Amendment's 'objective reasonableness' standard, rather than under a substantive due process standard." ${ }^{50}$ In vacating and remanding, the Court clarified that the Glick test should not be followed, and that the "objective reasonableness" standard should be used instead. ${ }^{51}$ The "reasonableness" of use of force, to the Court, requires avoiding the "20/20 vision of hindsight" by looking at the events from the perspective of a "reasonable officer on the scene," while taking into account the fact that officers make "split-second judgments" in "circumstances that are tense, uncertain, and rapidly evolving." 52 In so doing, the Court solidified the Fourth Amendment "objective reasonableness" standard as the only way to evaluate police excessive force in the context of effectuating an arrest, while avoiding creating any bright-line rules to actually guide officers in using force..$^{53}$ In effect, Graham would get the Court out of the business of making

45 Graham v. Connor, 490 U.S. 386, 388-89 (1989).

${ }^{46} I d$. at $389-90$.

47 Id. at 390.

48 Id.; Johnson v. Glick, 481 F.2d 1028, 1033 (2d Cir. 1973) (The test used in Glick instructed: "In determining whether the constitutional line has been crossed, a court must look to such factors as the need for the application of force, the relationship between the need and the amount of force that was used, the extent of injury inflicted, and whether force was applied in a good faith effort to maintain or restore discipline or maliciously and sadistically for the very purpose of causing harm"), overruled by Graham, 490 U.S. 386.

49 Graham, 490 U.S. at 391.

${ }^{50} \mathrm{Id}$. at 388. The Court notes that in excessive force claims made in response to an arrest, the Fourth Amendment is the exclusive mechanism. See id. at 394. For excessive force claims made by persons who are criminally convicted and incarcerated, the Eight Amendment applies. See id.

51 Id. at 399.

52 Id. at 396-97.

53 Scott v. Harris in 2007 only furthered this trend. See 550 U.S. 372, 383 (2007) ("Although respondent's attempt to craft an easy-to-apply legal test in the Fourth Amendment context is admirable, in the end we must still slosh our way through the factbound morass of 'reasonableness.' Whether or not 
any real decisions on what constitutes unconstitutional use of force, as it arguably did in Garner.

\section{B. Scholarship on Police Use of Force}

Generally speaking, scholarship on police use of force in the constitutional law space remains relatively sparse. ${ }^{54}$ Existing literature discussing police violence and constitutional law provides important critiques of Supreme Court case law and the limitations and flaws therein. However, the literature remains primarily critical of the Fourth Amendment, with little discussion of the potential of the Fourteenth Amendmentspecifically, equal protection - to address the use of force as an issue that implicates racialized group dynamics or social structures that replicate inequality in the shadow of the country's longstanding race problems. ${ }^{55}$

Scott's actions constituted application of 'deadly force,' all that matters is whether Scott's actions were reasonable." (emphasis added)); Garrett \& Stoughton, supra note 40, at 217 ("The turn away from Garner was cemented by the Court's 2007 decision in Scott v. Harris, which reinforced the approach in Graham by holding that there are no clearly impermissible uses of deadly force.").

${ }^{54}$ Police violence remains an undertheorized and underdiscussed issue in general in legal scholarship. See, e.g., ZIMRING, supra note 3, at 8-9 (describing the "[a]bsence of [1]egal [s]cholarship" on police violence); Rachel A. Harmon, When Is Police Violence Justified?, 102 NW. U. L. REv. 1119, 1122-23 (2008) (discussing the fact that legal scholars - criminal procedure scholars in particular-have focused primarily on other facets of policing apart from use of force).

55 See e.g., Linda Sheryl Greene, Before and After Michael Brown-Toward an End to Structural and Actual Violence, 49 WASH. U. J.L. \& POL'Y 1, 4 (2015) (focusing less on the particular role of constitutional law but arguing that "individual instances of police deadly force against unarmed Black men are enabled by a legal jurisprudence of structural violence which provides no accountability for the societal marginalization and stigmatization of young Black men, as well as by a jurisprudence of actual violence, which permits police officers to decide whom to target and whom to kill with virtually no threat of criminal sanction or institutional civil liability"). But see Wayne C. Beyer, Police Misconduct: Claims and Defenses Under the Fourteenth Amendment Due Process and Equal Protection Clauses, 30 URB. LAW. 65, 65 (1998) ("Second to the Fourth Amendment's protection from unreasonable searches and seizures, the Fourteenth Amendment's Due Process and Equal Protection Clauses furnish the greatest protection from police abuse."); Blanche Bong Cook, Biased and Broken Bodies of Proof: White Heteropatriarchy, the Grand Jury Process, and Performance on Unarmed Black Flesh, 85 UMKC L. REV. 567, 621 (2017) (engaging in a brief discussion of equal protection in the context of police violence); Zach Newman, Note, "Hands Up, Don't Shoot": Policing, Fatal Force, and Equal Protection in the Age of Colorblindness, 43 HASTINGS CONST. L.Q. 117, 136-42 (2015) (discussing how the Supreme Court has largely foreclosed the possibility of mobilizing the Equal Protection Clause (in part, due to the intent doctrine introduced in Washington v. Davis) in the context of police violence). Additionally, while not necessarily pertaining directly to Graham and fatal force usage, interesting discussions of the role of the Fourth Amendment in precipitating violent interchanges between citizens and police are emerging, especially in Devon Carbado's scholarship. See, e.g., Devon W. Carbado, From Stopping Black People to Killing Black People: The Fourth Amendment Pathways to Police Violence, 105 CALIF. L. REV. 125, 127 (2017) [hereinafter Carbado, Fourth Amendment Pathways]; Devon W. Carbado, Predatory Policing, 85 UMKC L. REV. 545, 546 (2017) [hereinafter Carbado, Predatory Policing] ("A variety of social forces (including broken windows policing, racial stereotypes, racial segregation, and Fourth Amendment law) converge to make African-Americans vulnerable to ongoing police surveillance and contact." (emphasis added)). Finally, see Jack Glaser's scholarship on racial profiling as an important element of the process 
As an example of the nature of recent scholarship in this area, Rachel Harmon writes that the Supreme Court's Fourth Amendment jurisprudence is "deeply impoverished" and "incomplete and indeterminate." 56 To Harmon, a reasonable use of force under the Fourth Amendment must be understood as existing only in response to an "imminent threat," where the force is necessary in terms of "degree and kind" and the harm to the citizen is not "substantially disproportionate" to the harm it tries to prevent. ${ }^{57}$ In devising a new standard under the Fourth Amendment, Harmon contends that the Fourth Amendment can be improved by incorporating the concepts of imminence, necessity, and proportionality that are part of a justification defense in criminal law. ${ }^{58}$

Brandon Garrett and Seth Stoughton contend that the Fourth Amendment can be resurrected into a more tactical and effective constitutional framework that actually protects citizens..$^{59}$ To these authors, Graham and its progeny are "counterproductive," having hindered sound police tactics and training and "confounding efforts to draft clear use-offorce policies." ${ }_{60}$ They argue that, despite this, "Fourth Amendment use-offorce doctrine can be reimagined" and, if courts fail to do their job of incorporating good tactics into Fourth Amendment doctrine, the Amendment will "fade into irrelevance." ${ }_{11}$ Finally, like other scholarship noted here, Garrett and Stoughton contend that Tennessee v. Garner provides "crucial insights" that have been lost and "need to be recovered." 62

Similarly, Nancy Marcus argues that Garner should be revived in the Fourth Amendment context, with the goal that it serve to define police violence case law instead of Graham. ${ }^{63}$ "[T] addressing the circumstances of his death by police shooting, set forth a firm rule of law establishing that shooting at unarmed or otherwise dangerous fleeing suspects as a method of stopping them from escaping is prohibited

\footnotetext{
of deciding whom to stop (and potentially subject to force) as well as L. Song Richardson and Phillip Goff's scholarship on suspicion heuristics. JACK GLASER, SUSPECT RACE: CAUSES AND CONSEQUENCES OF Racial Profiling 21-41 (2015); L. Song Richardson \& Phillip Atiba Goff, Self-Defense and the Suspicion Heuristic, 98 IowA L. REV. 293, 295-96 (2012).

56 Harmon, supra note 54, at 1119-20.

${ }^{57}$ Id. at 1120.

58 Id. at 1124.

${ }^{59}$ Garrett \& Stoughton, supra note 40, at 213-14.

${ }^{60} \mathrm{Id}$. at 217.

${ }^{61} I d$. at 214

62 Id. at 224 .

63 Marcus, supra note 40, at 82; see also Nancy C. Marcus, Out of Breath and Down to the Wire: A Call for Constitution-Focused Police Reform, 59 How. L.J. 5, 38 (2015) (making similar contentions regarding the importance of Garner).
} 
by the Constitution." ${ }^{64}$ To Marcus, Garner represents a clear rule precluding lethal force in certain situations, unlike the abstract vagaries of Graham. ${ }^{65}$ We can use Garner while criticizing Graham, Marcus contends. ${ }^{66}$ In other words, Garner should "not be thrown out with the bathwater" despite the failure of Graham. ${ }^{67}$ In a similar vein, John Gross contends that the Supreme Court has produced a standard of review that is "highly deferential" to police and has failed to provide "meaningful guidance" on when deadly force is allowed. ${ }^{68}$ Gross further argues that the Fourth Amendment "insulates" officers from liability through the reasonableness standard. ${ }^{69}$ To Gross, this all makes it an "uphill battle" to bring a $§ 1983$ suit alleging a constitutional violation. ${ }^{70}$

To be sure, scholars have certainly looked at how issues of race and racism interact with policing practices shaped by the Fourth Amendment. For example, Devon Carbado and Patrick Rock argue:

[F]or all the discussions we have had about race and excessive force over the past decade, our understanding of the phenomenon has not much improved. In part, this is because we continue to frame excessive force as a problem that derives from rogue police officers who harbor racial animus against African Americans. $^{71}$

Carbado and Rock caution that such framings ignore the structural dimensions of police violence. They then leverage recent findings in social psychology to draw attention to the complexity of the cognitive processes leading up to violent encounters. Carbado writes in a separate piece about policing procedures permitted by the Fourth Amendment (such as racial profiling) that allow the police to "force interactions with African Americans with little or no basis" 72 that often end violently. Carbado then lays out how the Court's interpretation of the Fourth Amendment allows for various forms of racial profiling and thus "facilitates the precarious line between stopping black people and killing black people."’3

\footnotetext{
${ }^{64}$ Marcus, supra note 40, at 55-56 (citing Tennessee v. Garner, 471 U.S. 1, 3 (1985)).

${ }^{65} I d$. at 82.

${ }^{66} I d$. ("Not only is it possible for police reform advocates hoping to rein in excessive police violence to simultaneously criticize the vagueness of the Graham and embrace the central holding of Garner, it makes sense to do so.").

${ }^{67} \mathrm{Id}$.

${ }^{68}$ Gross, supra note 35 , at $155-56$.

${ }^{69} \mathrm{Id}$. at 165 .

$70 \mathrm{Id}$.

71 Devon W. Carbado \& Patrick Rock, What Exposes African Americans to Police Violence, 51 Harv. Civ. RTS.-Civ. Liberties L. Rev. 159, 161 (2016).

72 Carbado, Fourth Amendment Pathways, supra note 55, at 127.

73 Id. at 129 .
} 
Other scholars have made similar important points about how the Fourth Amendment codifies rather than checks the ability of police officers to disproportionately harass people of color. ${ }^{74}$ This work has been important, if not transformative, in its insistence that police violence is a deep-seated structural problem facilitated by the Fourth Amendment rather than an aberration to an otherwise neutral jurisprudence. However, this literature has largely examined how the Fourth Amendment precipitates disproportionate police contact with people of color, which allows officers' individual bias and institutional forms of racism to manifest in violent engagements with people of color. This is a separate, yet related, point to the issue raised by this Essay, which attempts to understand the broader doctrinal choices made by the Supreme Court that pave certain conceptual pathways and foreclose others. These doctrinal choices shape our understanding of excessive force claims as a dispute governed by an individualist Fourth Amendment rather than by constitutional text that may be more attuned to the group-based racial dynamics embedded in these violent interactions, such as the Equal Protection Clause of the Fourteenth Amendment.

\section{Implications}

It is in this scholarly and doctrinal context that focuses almost exclusively on the Fourth Amendment in understanding the parameters of police use of force that we ask a simple empirical question: Has it always been this way? Put differently, to the extent that Graham holds that matters concerning police use of force should be analyzed under the Fourth Amendment, we seek to understand the on-the-ground impact that Graham has had by comparing post-Graham data on federal courts' decision-making to a similar dataset comprised of cases decided before Graham's doctrinal implementation. While the Supreme Court used Graham to push police excessive force analyses into the limited, individualized terrain of the Fourth Amendment - and scholars have remained largely silent on the potentiality of a different constitutional terrain - we seek to add to the existing literature by providing an empirical examination of what Graham's doctrinal shift has meant for how federal courts understand and approach matters concerning police violence.

\footnotetext{
74 See, e.g., Tracey Maclin, Race and the Fourth Amendment, 51 VAND. L. REV. 333, 337-40 (1998); Jordan Blair Woods, Decriminalization, Police Authority, and Routine Traffic Stops, 62 UCLA L. ReV. 672, 683-84 (2015).
} 


\section{Qualitative ANAlysis of PRE- AND POST-GRAHAM POLICE EXCESSIVE FORCE CASE LAW}

The preceding sections provided a historical, doctrinal, and scholarly context for our research questions: What impact did the Supreme Court's holding in Graham have on how federal courts approach excessive force claims? How did federal courts analyze these claims before Graham? Did Graham shift this jurisprudence, or did it merely restate an approach that was already in consensus among federal courts?

To have an empirical understanding of Graham's impact in framing these adjudications, we conducted a qualitative study of federal case law twenty-six years prior to and after the 1989 Graham decision in order to capture how federal courts conceptualize matters pertaining to police excessive force and the legal claims they recognize and apply. Specifically, we systematically studied how federal courts analyze police excessive force claims pre- and post-Graham and the evolving roles played by the Fourth and Fourteenth Amendments.

\section{A. Methods}

In order to facilitate a qualitative comparison between the two time periods, we coded a random sample of 250 reported federal cases pertaining to police excessive force pre-Graham, 1962 to 1988, and 250 cases postGraham, from 1990 to $2016 . .^{75}$ We identified a dataset of cases through a Westlaw database search and used a random number generator to select cases that were then subjected to inclusion criteria until we had a total of 500 qualifying cases. ${ }^{76}$

We read and coded each qualifying case. We used five main codes: whether ("yes" or "no") the Fourth Amendment, $\S 1983,{ }^{77}$ the Fourteenth

\footnotetext{
75 The Court decided Graham v. Connor on May 15, 1989. Since this was a midyear decision, we excluded 1989 from our search to facilitate a more precise understanding of how courts approached police violence matters before and after the decision.

76 We randomly sampled 500 qualifying cases during this period in order to have a reasonable number of cases from which to draw inferences about the entire dataset. For the dataset of cases decided before Graham, we searched for "police," "police officer," and "excessive force or excessive use of force" for the given time period for reported federal cases, resulting in 1,029 hits. For the dataset comprised of cases decided after Graham, we conducted the same search, and it resulted in 2,708 hits. We chose to use the term "excessive force" for both time periods for continuity. Finally, for each time period, cases that did not have to do with police use of force in the context in which we are discussing it were excluded. Specifically, cases involving subjects like pretrial detention in jail or incarceration in prison or a medical facility were excluded because - in terms of the temporality of the criminal justice process - there are different constitutional analyses that arise that would affect our research question, which is solely focused on police use of force during their everyday patrols.

77 Section 1983 provides a civil right of enforcement for a violation of a constitutional right. It is generally held to not confer any substantive rights, but rather is a "method for vindicating federal rights
} 
Amendment, the Equal Protection Clause, or the race of victim or officer was discussed in the case. ${ }^{78}$ This provided us with a sense of the constitutional meta-narratives courts follow in this field, in terms of the frequency with which constitutional protection was mobilized. Regarding cases coded as "Fourteenth Amendment," it is important to note that these data pertain to the Fourteenth Amendment overall - both in terms of substantive due process claims and equal protection claims in the excessive force realm. In reviewing and coding the cases, not all plaintiffs were clear about which portion of the Fourteenth Amendment they used to support their claims. Similarly, courts did not always rearticulate plaintiffs' Fourteenth Amendment claims with specificity. Section III.B.3 of this Part discusses our findings that specifically engage the Equal Protection Clause of the Fourteenth Amendment. It was important to identify and track when courts explicitly mentioned this portion of the Fourteenth Amendment, as equal protection speaks directly to issues of race and group inequality beyond individuals. By examining both the overarching discourse surrounding the Fourteenth Amendment as well as particular claims concerning equal protection, we could better understand the ways in which they have separately as well as jointly been discussed.

We also used an additional set of "subcodes" to understand what happened if and when the Fourteenth Amendment and Equal Protection Clause were coded as "yes." In other words, just because the Fourteenth Amendment or the Equal Protection Clause was mentioned, it might have been in a negative fashion, and so we wanted to uncover the logic through which courts thought about these claims. Hence, if the Fourteenth Amendment was coded as "yes," we then noted how courts discussed it. If the Equal Protection Clause was coded as "yes," we similarly coded for the way courts discussed it. There were four possible subcodes: "rejected," "accepted," "not about race," and "about race." "Rejected" signifies that the court rejected the claim; "accepted" signifies that the court accepted the claim in some way; "not about race" means the plaintiff"s equal protection claim was not about race (e.g., arguing victim of police violence was part of

\footnotetext{
elsewhere conferred." Baker v. McCollan, 443 U.S. 137, 144 n.3 (1979). However, as the Court in Graham observed, "many courts have seemed to assume, as did the courts below in this case, that there is a generic 'right' to be free from excessive force, grounded not in any particular constitutional provision but rather in "basic principles of $\S 1983$ jurisprudence." Graham v. Connor, 490 U.S. 386, 393 (1989) (quoting Justice v. Dennis, 834 F.2d 380, 382 (4th Cir. 1987), vacated, 490 U.S. 1087 (1989) (remanding the case in light of Graham)). The Graham Court explicitly rejected this approach in favor of funneling all excessive force claims through the Fourth Amendment standard. Id. at 393-94. However, given that $\S 1983$ was one of the many ways in which federal courts understood the boundaries of these claims, we coded for it.

78 These codes were used because they are the concepts that we were interested in comparing between the pre- and post-Graham datasets.
} 
another protected class); and "about race" signifies it was an equal protection claim that was actually about race. Finally, we coded to see if courts mentioned the race of the victim or officer involved in the violent engagement. If either was mentioned, we coded for the racial identity as described by the court in that case.

This coding gives us a sense of each court's approach and rationaleparticularly if the court includes or rejects claims beyond the Fourth Amendment. Below, Table 1 provides a visual description for how this coding functioned, with the six subcodes for the Fourteenth Amendment, the four subcodes for the Equal Protection Clause, and the five subcodes for race of victims and officers.

TABLE 1: CODES AND SUBCODES

\begin{tabular}{|c|c|c|c|}
\hline $\begin{array}{l}\text { If the Fourteenth } \\
\text { Amendment was } \\
\text { mentioned, how } \\
\text { was it treated by } \\
\text { court? }\end{array}$ & $\begin{array}{l}\text { If the Equal } \\
\text { Protection Clause } \\
\text { was mentioned, } \\
\text { what was the } \\
\text { result? }\end{array}$ & $\begin{array}{l}\text { If victim's race was } \\
\text { mentioned, how } \\
\text { was it identified? }\end{array}$ & $\begin{array}{c}\text { If officer's race was } \\
\text { mentioned, how was } \\
\text { it identified? }\end{array}$ \\
\hline $\begin{array}{l}\text {-Plaintiff raises and } \\
\text { court ignores or applies } \\
\text { Fourth Amendment } \\
\text { with no discussion } \\
\text {-Plaintiff raises and } \\
\text { court discusses and } \\
\text { rejects—or doesn't } \\
\text { reach Fourteenth } \\
\text { Amendment question- } \\
\text { in favor of Fourth } \\
\text { Amendment } \\
\text {-Plaintiff raises and } \\
\text { court discusses and } \\
\text { accepts but unfavorable } \\
\text { to plaintiff } \\
\text {-Plaintiff raises and } \\
\text { dismissed or plaintiff } \\
\text { raises and court ignores } \\
\text { but doesn't apply } \\
\text { Fourth Amendment } \\
\text { either } \\
\text { •Raised by court } \\
\text { without plaintiff or } \\
\text { raised by defendants } \\
\text { without plaintiff } \\
\text { •Plaintiff raises and } \\
\text { court discusses and } \\
\text { accepts and finds } \\
\text { favorably for plaintiff }\end{array}$ & $\begin{array}{l}\cdot \text { Rejected } \\
\cdot \text { Accepted } \\
\cdot \text { Not About Race } \\
\text {-About Race }\end{array}$ & $\begin{array}{l}\cdot \text { African-American } \\
\cdot \text { White } \\
\cdot \text { Latino/a } \\
\text {-Asian-American } \\
\text {-Native American }\end{array}$ & $\begin{array}{l}\cdot \text { African-American } \\
\cdot \text { White } \\
\cdot \text { Latino/a } \\
\cdot \text { Asian-American } \\
\cdot \text { Native American }\end{array}$ \\
\hline
\end{tabular}




\section{B. Findings and Discussion}

The findings indicate that before Graham, federal courts infrequently relied upon the Fourth Amendment in adjudicating the constitutionality of police use of force (see Figure 1 below). Only $28.0 \%$ of the qualifying preGraham cases include a discussion of the Fourth Amendment. Moreover, the cases in this pre-Graham dataset (a) almost always discussed $\S 1983$ (96.0\%); (b) sometimes discussed the Fourteenth Amendment (40.0\%); and (c) rarely discussed the Equal Protection Clause specifically (10.4\%), the race of the victim $(15.6 \%)$, or the race of the officer $(6.0 \%)$. Thus, the preGraham data suggest that there was less emphasis on the Fourth Amendment during this time period.

The post-Graham findings moved in a different direction, where $90.4 \%$ of the cases in this dataset discussed the Fourth Amendment. As the cause of action for individuals to claim a constitutional violation related to police excessive force, it is unsurprising that $\S 1983$ remained prominent $(96.4 \%)$. The Fourteenth Amendment was mentioned in $25.6 \%$ of the cases while the Equal Protection Clause was specifically mentioned in 5.2\%. Race of the victim was mentioned in $17.2 \%$ of the sampled cases while race of the officer was mentioned $2.8 \%$ of the time. The post-Graham data suggest a significant focus on the Fourth Amendment and less on other areas of the Constitution. ${ }^{79}$ This is not surprising, given the holding in Graham.

The real surprise, however, is how seldom federal courts discussed the Fourth Amendment in relation to excessive force claims prior to Graham. These trends suggest that, post-Graham, the Supreme Court (a) effectively channeled police violence matters into the preexisting individualized constitutional terrain of the Fourth Amendment in a manner that substantially deviated from its pre-Graham jurisprudence (increasing from $28.0 \%$ of cases to $90.4 \%$ ); (b) moved away from examining police violence matters through the Fourteenth Amendment (decreasing from $40.0 \%$ to $25.6 \%$ ); and, finally, (c) moved away from the group-sensitive potentiality of equal protection analyses (decreasing from $10.4 \%$ to $5.2 \%$ ) as well as continuing to avoid an explicit acknowledgement of the race of victims or officers across both time periods, which further entrenches notions of "colorblindness" 80 in excessive

\footnotetext{
${ }^{79}$ In evaluating excessive force claims, $79.6 \%$ of the cases mention Graham in some fashion.

80 See Michelle AleXander, The New Jim Crow: Mass Incarceration in the Age of COLORBLINDNESS 183-84 (rev. ed. 2012) ("Our understanding of racism is therefore shaped by the most extreme expressions of individual bigotry, not by the way in which it functions naturally, almost invisibly (and sometimes with genuinely benign intent), when it is embedded in the structure of a social system.”); EdUARdo Bonilla-Silva, RACISM Without RACISTS: COlOR-Blind RACISM AND THE PERSISTENCE OF RACIAL INEQUALITY IN AMERICA 2 (4th ed. 2014) (describing the "ideology" of "color-blind racism" as explaining "contemporary racial inequality as the outcome of nonracial dynamics"). See generally Osagie K. OBAsogie, Blinded by Sight: SEeing RaCe Through the Eyes OF The Blind (2014); Tim
} 
force assessments. Put another way, the Supreme Court's holding in Graham produced rather than mirrored any consensus or normative understanding regarding police excessive force claims being rendered as Fourth Amendment concerns. A more detailed discussion appears below.

Figure 1: Federal Court Evaluations of Police Violence Pre- and Post-Graham

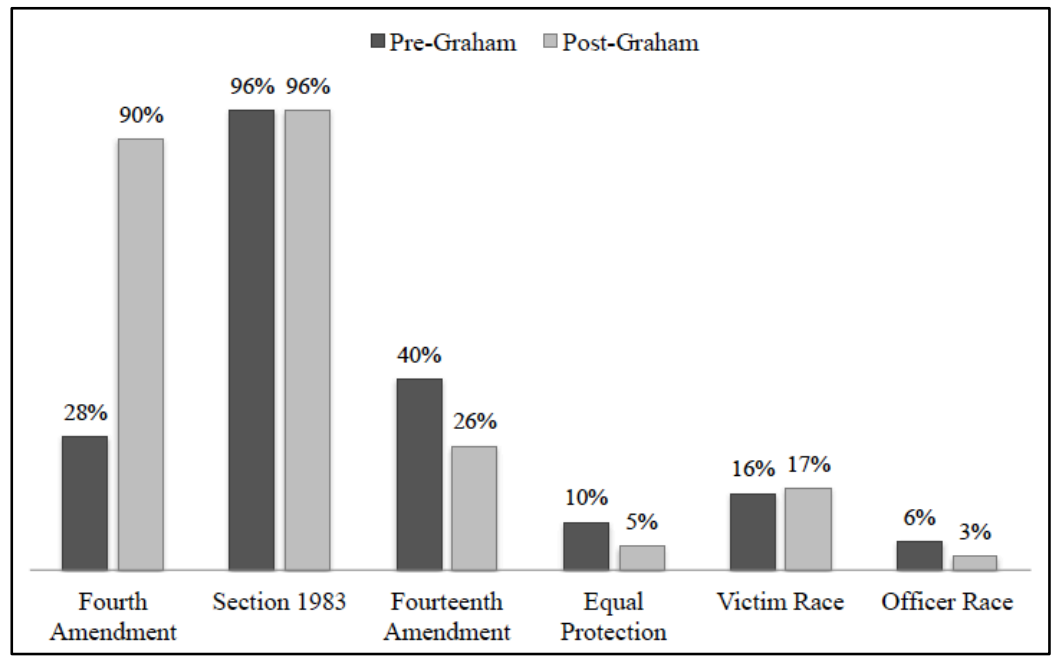

\section{Channeling Toward the Fourth Amendment}

This post-Graham focus on the Fourth Amendment is not shocking; plaintiffs likely thought it would not help their case to base excessive force claims on anything but the Fourth Amendment after the Graham Court's declarative statement. ${ }^{81}$ However, what is important to keep in mind is the relatively low percentage of cases prior to Graham that discussed or referenced the Fourth Amendment. In other words, this means that a discussion of the Fourth Amendment pre-Graham was not all that common. The shift from $28.0 \%$ to $90.4 \%$ reflects a tremendous imposition of normative boundaries concerning constitutional claims regarding excessive force and the Supreme Court's effort to channel this conversation towards

Wise, Colorblind: The Rise of Post-Racial Politics and the Retreat From Racial EQuity (2010).

81 The Graham Court noted:

Today we make explicit what was implicit in Garner's analysis, and hold that all claims that law enforcement officers have used excessive force-deadly or not-in the course of an arrest, investigatory stop, or other "seizure" of a free citizen should be analyzed under the Fourth Amendment and its "reasonableness" standard, rather than under a "substantive due process" approach. Because the Fourth Amendment provides an explicit textual source of constitutional protection against this sort of physically intrusive governmental conduct, that Amendment, not the more generalized notion of "substantive due process," must be the guide for analyzing these claims. Graham, 490 U.S. at 395. 
the individualist Fourth Amendment discourse and away from Fourteenth Amendment and equal protection claims that were, according to our data, perceived as legitimate jurisprudential pathways to follow prior to Graham. Thus, the data suggest that the Supreme Court did not necessarily choose the Fourth Amendment terrain for understanding the constitutional boundaries of excessive force claims because it reflected the most common understanding among the federal courts. Instead, the data suggest that this path was chosen due to other ideological commitments concerning how the Supreme Court thinks we ought to conceive and bound the relationship between constitutional text and plaintiffs' rights to be free from state hyperaggressions.

This discourse entrenching the primacy of the Fourth Amendment can be seen in the language used by the lower courts after the Graham decision. For example, in responding to a plaintiff's excessive force claim, a district court in Pennsylvania characterized the Court's holding in Graham as standing for the idea "that the sole source of constitutional protection against the use of force in the context of an arrest, investigatory stop or other type of seizure is the [F]ourth [A]mendment." 82 Similarly, a lower court in Alabama noted further that Graham stands as having "determined that the Fourth Amendment applies to all claims alleging a police officer used excessive force in the course of an arrest, investigatory stop or other 'seizure' of a free citizen." "83 Finally, the Seventh Circuit Court of Appeals wrote that "Graham $v$. Connor... held that all excessive force claims against law enforcement officers... must be analyzed under the Fourth Amendment's 'objective reasonableness' standard." $" 84$

Altogether, this language typifies the discourse through which courts declare the Fourth Amendment the sole constitutional right involved in matters concerning police excessive force. The fact that there is more than a $60 \%$ difference in how federal courts discuss the relevance of the Fourth Amendment to police excessive force claims pre- and post-Graham highlights the extent that, before Graham, lower courts deemphasized the Fourth Amendment in excessive force cases and were open to multiple ways of thinking through the constitutional standard.

In addition, while the Fourth Amendment became centralized, what remained constant was the role of $\S 1983$. Of the cases surveyed post-

\footnotetext{
82 Janicsko v. Pellman, 774 F. Supp. 331, 341 (M.D. Pa. 1991) (emphasis added).

83 Hamilton v. City of Jackson, 508 F. Supp. 2d 1045, 1053 (S.D. Ala. 2007) (emphasis added).

${ }^{84}$ McDonald v. Haskins, 966 F.2d 292, 293 (7th Cir. 1992) (emphasis added); see also Hancock v. Dodson, 958 F.2d 1367, 1374 (6th Cir. 1992) (“Claims of excessive force under section 1983 are properly analyzed under the $[\mathrm{F}]$ ourth $[\mathrm{A}]$ mendment's prohibition against unreasonable seizures of the person, and its corresponding reasonableness standard.").
} 
Graham, 96.4\% discussed $\S 1983$, which means that most of the time if a Fourth Amendment claim was being made, it was being made alongside a $\S 1983$ claim. Similarly, $96.0 \%$ of pre-Graham cases featured $\S 1983$. Thus, while $\S 1983$ had a primary role in pre-Graham cases as compared to the Fourth Amendment, the Fourth Amendment rose to prominence after Graham to operate in conjunction with $\S 1983$ in bringing police violence cases. This is consistent with the language in Graham, which identified a trend at the time where "many courts ... seemed to assume, as did the courts below in this case, that there is a generic 'right' to be free from excessive force, grounded not in any particular constitutional provision but rather in 'basic principles of $\S 1983 \ldots$..." ${ }_{85}$ The Graham court rejected this view, stating that " $§ 1983$ 'is not itself a source of substantive rights,' but merely provides 'a method for vindicating federal rights elsewhere conferred"' thus largely bootstrapping the method for seeking a private remedy$\S 1983$ - to the Fourth Amendment as the standard for what constitutes a violation of one's constitutional rights. ${ }^{87}$

\section{Impeding the Fourteenth Amendment}

The Fourteenth Amendment provides an interesting alternative framework from which to think about excessive force by police. As one of the post-Civil War Reconstruction Amendments, it reflects a constitutional moment where law formally became cognizant of how differential group status can lead to inequality. This sensibility is reflected through claims of substantive due process protecting fundamental rights that arise, at least in part, out of the Fourteenth Amendment, as well as through the amendment's Equal Protection Clause, which provides a more direct framework to address group inequities. ${ }^{88}$

The data indicate that the Fourteenth Amendment had legitimate traction prior to Graham; appearing in $40.0 \%$ of the cases, it can be seen as part of the suite of mechanisms federal courts used to think through constitutional standards pertaining to excessive force. After Graham, there is a drop-off in the prevalence of the Fourteenth Amendment while the

\footnotetext{
85 Graham, 490 U.S. at 393.

${ }^{86}$ Id. at 393-94 (quoting Baker v. McCollan, 443 U.S. 137, 144 n.3 (1979)).

87 "In addressing an excessive force claim brought under $\S 1983$, analysis begins by identifying the specific constitutional right allegedly infringed by the challenged application of force.... In most instances, that will be either the Fourth Amendment's prohibition against unreasonable seizures of the person, or the Eighth Amendment's ban on cruel and unusual punishments, which are the two primary sources of constitutional protection against physically abusive governmental conduct." Id. at 394. The Court goes on to state that the Fourth Amendment is applicable to claims of excessive force when police are trying to make an arrest, while the Eight Amendment applies to excessive force claims made by a person who is incarcerated. Id. at 389-91.

88 See infra Section III.B.3.
} 
Fourth Amendment rose to prominence. However, the fact that Fourteenth Amendment claims appeared $25.6 \%$ of the time in the post-Graham dataset is only half of the story. Of the times they did appear, in the vast majority of those instances $(82.8 \%)$ the claims were ultimately unsuccessful in some way. Thus, Fourteenth Amendment claims were not received well when brought to courts: of the instances where they were included, only $10.9 \%$ of the time did the court actually discuss the claim, accept that the Fourteenth Amendment applied, and then find at least somewhat favorably for the plaintiff. ${ }^{89}$ The following Section describes how courts treated Fourteenth Amendment claims when they did appear, and how courts treated these claims in a mostly negative fashion.

\section{a. Blocking Fourteenth Amendment claims post-Graham}

There were two primary ways that a court would get rid of the postGraham Fourteenth Amendment claim when it was included: (1) ignoring the claim by not engaging with it (23.4\%) or (2) discussing but rejecting the premise of the claim (i.e., that the Fourteenth Amendment is not relevant in the police violence context) without actually reaching the merits of the claim (42.2\%). Hence, the court ignored or discussed but rejected the claim 65.6\% of the time. This means that most of the time the court did not engage the Fourteenth Amendment claim fully, but disposed of it rather quickly. Furthermore, $12.5 \%$ of the time the court would actually engage with and accept the Fourteenth Amendment claim, but subsequently come to an unfavorable decision.

Hence, even if the court accepted that perhaps the Fourteenth Amendment was applicable, it might still proceed to just reject the claim itself. Accordingly, $82.8 \%$ of the time the Fourteenth Amendment was met with resistance in one of these ways: the Fourteenth Amendment was not addressed or was explicitly rejected in favor of the Fourth Amendment (65.6\%); the court found unfavorably for the plaintiff even though it accepted the claim's viability (12.5\%); or the claim was dismissed by the plaintiff herself or the court did not address it or the Fourth Amendment (4.7\%). ${ }^{90}$

\section{(i) Ignoring the claim}

First, in those cases where the courts ignored or did not mention the claim $(23.4 \%)$, the case would often consist of the plaintiff asserting the claim and the court just not addressing it again, and merely applying the

\footnotetext{
89 Of all 250 cases, this only occurred $2.8 \%$ of the time.

90 The court or the defendant(s) brought up the Fourteenth Amendment without the plaintiff doing so $6.3 \%$ of the time. In addition, to clarify the $4.7 \%$ statistic, this code included the situation wherein the court would not address the Fourteenth Amendment claim, but would not end up explicitly applying the Fourth Amendment either.
} 
Fourth Amendment following Graham ${ }^{91}$ For example, in one case from the District Court for the Southern District of Alabama, the court characterized the plaintiff's claim as follows: "The Plaintiff has alleged the Defendants violated his rights to be secure in his person and free of excessive force under the Fourth and Fourteenth Amendments." ${ }^{2}$ The court went on to immediately cite the Fourth Amendment and then Graham, as holding that "the Supreme Court determined that the Fourth Amendment applies to all claims alleging a police officer used excessive force in the course of an arrest, investigatory stop or other 'seizure' of a free citizen." ${ }^{93}$ The court concluded that, "[t]herefore, the Plaintiff's claim of unreasonable or excessive force must be analyzed under the Fourth Amendment." 94 Thus, this is one way that a court could get rid of a Fourteenth Amendment claim, by merely not engaging with it and, instead, just using the Fourth Amendment and Graham to evaluate the suit.

We note that in the "ignoring the claim" dataset, these are cases where the court describes the plaintiff as bringing both Fourth and Fourteenth Amendment claims and then proceeds only under a Fourth Amendment analysis. This discussion does not reflect some notion of incorporation (which is not mentioned in the cases) but rather a channeling of the excessive force claim into a singular Fourth Amendment analysis. What separates "ignoring" the claim from "rejecting" it (discussed below) is the level of engagement by the court.

\section{(ii) Rejecting the claim}

Second, for those cases where courts engage to a degree with the Fourteenth Amendment claim but ultimately reject it (42.2\%), the courts would generally note that the plaintiff filed a $\S 1983$ claim for violation of her constitutional rights under the Fourth and Fourteenth Amendments for use of excessive force. In doing so, the courts would respond to a motion from the defendants, usually a motion for summary judgment, and then proceed to state that the Fourth Amendment-not the Fourteenth-is the applicable standard for a police violence matter.

91 See, e.g., Estate of Lopez ex rel. Lopez v. Torres, 105 F. Supp. 3d 1148, 1155 (S.D. Cal. 2015) ("Excessive force claims relating to police conduct during an arrest must be analyzed under the Fourth Amendment and its reasonableness standard." (emphasis added)); Stevens v. Metro. Transp. Auth. Police Dep't, 293 F. Supp. 2d 415, 420 (S.D.N.Y. 2003) (including the Fourteenth Amendment, but stating that "[plaintiff] Stevens's claim that the police officers used excessive force to effect his arrest is analyzed under the Fourth Amendment's prohibition against unreasonable seizures of the person").

92 Hamilton v. City of Jackson, 508 F. Supp. 2d 1045, 1053 (S.D. Ala. 2007).

93 Id. (emphasis added).

94 Id. (emphasis added). 
For example, in a case from the Northern District of Ohio, the plaintiff brought suit against the police for using deadly force in violation of the decedent's Fourth and Fourteenth Amendment rights. ${ }^{95}$ The court wrote that the applicable standard is the Fourth Amendment: "A claim that the government used excessive force during the course of a seizure is analyzed under the Fourth Amendment's 'objective reasonableness' standard." 966 The court goes on to say that, while the plaintiff brings a Fourteenth Amendment claim as well as the Fourth Amendment claim, "[i]n the context of the right to be free from excessive force, however, the Sixth Circuit applies a Fourth Amendment seizure analysis to the claims." ${ }^{97}$ The court thus held that the Fourteenth Amendment did not have a role in the suit, just the Fourth Amendment.

In another example, a case from the Northern District of Illinois, the plaintiff brought a $\S 1983$ claim against the police for excessive use of force under the Fourth and Fourteenth Amendments. ${ }^{98}$ Defendant officers argued that the plaintiff's allegations under the Fourteenth Amendment must be dismissed because excessive force is "governed solely" by the Fourth Amendment. 99 The court agreed with the defendants, writing that "[f]ollowing Graham v. Connor... it is clear that an excessive force claim ... is 'properly analyzed under the Fourth Amendment[] . . rather than under a substantive due process standard." "'100 As a result, the court decided to "strike [plaintiff's] Fourteenth Amendment claims." Consequently, we see the court here explicitly rejecting plaintiff's Fourteenth Amendment claim in favor of the Fourth.

Last, in a case from the Western District of Tennessee, in his $\S 1983$ suit for excessive force, the plaintiff made both Fourth and Fourteenth Amendment claims. ${ }^{102}$ The defendant argued that the Fourteenth Amendment was inapposite, and the court proceeded to simply dismiss the claims the plaintiff brought under that Amendment. ${ }^{103}$ After dismissing the Fourteenth Amendment claim, the court then, citing Graham, applied the Fourth Amendment reasonableness test. ${ }^{104}$

\footnotetext{
95 Chappell v. City of Cleveland, 584 F. Supp. 2d 974, 976, 989 (N.D. Ohio 2008)

96 Id. at 989-90.

97 Id. at 976 n.1.

98 Green v. Saenz, 812 F. Supp. 798, 801 (N.D. Ill. 1992).

99 Id.

100 Id. (quoting Graham v. Connor, 490 U.S. 386, 388 (1989)).

$101 \mathrm{Id}$.

102 Phebus v. City of Memphis, 340 F. Supp. 2d 874, 882 (W.D. Tenn. 2004).

$103 \mathrm{Id}$.

104 Id. at $882-83$.
} 
In these examples, the courts overtly state that the Fourth Amendment is to be used, and not the Fourteenth, referring to Graham as precedent for this doctrinal move. Hence, what we see here is the way in which courts solidify a doctrine that exclusively handles police excessive force cases with the Fourth Amendment through both ignoring the Fourteenth Amendment as well as explicit pronouncement of the dominion of the Fourth Amendment at the expense of the Fourteenth.

\section{b. Pre-Graham Fourteenth Amendment claims}

Prior to Graham, there was at least some room to make a cognizable claim under the Fourteenth Amendment's Due Process Clause as opposed to only the Fourth Amendment. ${ }^{105}$ Whether ultimately successful or not, this could take different forms. For example, in a 1984 case from Pennsylvania, the plaintiff brought a $\S 1983$ claim after being beaten by officers. ${ }^{106}$ After determining that the claim was based on excessive use of force, "the court construe[d] plaintiff's complaint as claiming a deprivation of a liberty interest. Having determined that a liberty interest is involved, the court [had to then] decide whether plaintiff was deprived of that interest without due process of law in violation of the Fourteenth Amendment." 107 However, because the court determined the plaintiff had adequate state law remedies, the court dismissed his $\S 1983$ claim. ${ }^{108}$ Therefore, while the plaintiff was unsuccessful in this Fourteenth Amendment claim, there was at least some engagement with it by the court.

In a 1982 case from the Northern District of Ohio, the plaintiff brought suit against the local police department in Canton, Ohio, after police hit him

\footnotetext{
105 See, e.g., Robins v. Harum, 773 F.2d 1004, 1007 (9th Cir. 1985) ("The Robinses argue that the right to be free from excessive use of force by the police is a substantive due process right protected by the Fourteenth Amendment . . . ."); United Steelworkers of Am. v. Milstead, 705 F. Supp. 1426, 1436 (D. Ariz. 1988) ("A claim of excessive use of force in making an arrest is actionable under $\S 1983$ as a violation of the Fourteenth Amendment right to substantive due process . . . ." (citation omitted)); Kedra v. City of Philadelphia, 454 F. Supp. 652, 666 (E.D. Penn. 1978) ("Another recurring aspect of the complaint is the repeated allegation of physical beatings. Such conduct is actionable as a civil rights violation since it deprives a person of his liberty interest in personal security without due process of law." (citation omitted)); Campbell v. Buckles, 448 F. Supp. 288, 290 (E.D. Tenn. 1976) ("The use of an excessive and unreasonable amount of force by state law enforcement officers in effectuating an arrest is a violation of the victim's right to due process of law, Constitution, Fourteenth Amendment." (citation omitted)).

106 Dobson v. Green, 596 F. Supp. 122, 124 (E.D. Penn. 1984).

107 Id.; see also Reed v. Phila. Hous. Auth., 372 F. Supp. 686, 689 (E.D. Penn. 1974) ("This right [to be free from intentional and unprovoked assault by a police officer] is thought to arise from the due process clause of the Fourteenth Amendment, a right to be secure in one's person which stands separate and apart from any specific right found in the Bill of Rights. Application of undue force by law enforcement officers thus deprives the individual of liberty without due process of law." (citation omitted)).

108 Dobson, 596 F. Supp. at 125.
} 
in the head with a "billy club." 109 Here, the court found in favor of the plaintiff, noting that it could not find that the officer "acted in a 'good faith' belief that it was necessary to use force to effect [plaintiff] Taylor's arrest, when neither [the police officer] nor anyone else ever even attempted to arrest [the victim]." 110 The court further recognized that the officer's "actions were totally without provocation, justification, or probable cause, and they constitute an infringement by him of [the victim's] constitutional rights in violation of the Fourteenth Amendment and 42 U.S.C. § 1983."'111

In a case from New Jersey in 1979, a family member of the decedent, who was accidentally shot and killed as a bystander by police, brought a $\S 1983$ claim for damages. ${ }^{112}$ According to this court: "It is beyond dispute that one killed by a state police officer is deprived of his [F]ourteenth [A]mendment right to life." 113 The court rejected the defendant police department's claim for summary judgment. ${ }^{114}$ Finally, in a case from the Northern District of New York in 1984, one of the plaintiffs was struck with a "five cell, foot long metal flashlight." 115 In examining the excessive force claim brought under $\S 1983$ by the plaintiff, the court declared: "Application of undue force by law enforcement officers deprives an individual of the [F]ourteenth [A]mendment right to be secure in his person and thus represents a deprivation of liberty without due process of law." 116 The plaintiff received compensatory damages but no punitive damages against the officer. ${ }^{117}$

What these data and examples show is that before Graham, lower courts were at least somewhat more able - or willing — to engage in an analysis of the Fourteenth Amendment and due process in evaluating excessive force claims and, in this way, offered a meaningful alternative to the limitations of the Fourth Amendment. ${ }^{118}$ While the pre-Graham engagement with the

\footnotetext{
109 Taylor v. Canton, Ohio Police Dep't, 544 F. Supp. 783, 785 (N.D. Ohio 1982).

$110 \mathrm{Id}$. at 788 .

111 Id.

112 Popow v. City of Margate, 476 F. Supp. 1237, 1240 (D.N.J. 1979).

113 Id. at 1242.

114 Id. at 1240 .

115 Keyes v. City of Albany, 594 F. Supp. 1147, 1151 (N.D.N.Y. 1984).

116 Id. at 1154 (citation omitted).

117 Id. at 1155 .

118 See, e.g., Hornung v. Vill. of Park Forest, 634 F. Supp. 540, 544 (N.D. Ill. 1986) ("Claims of excessive force during arrest are cognizable under $\S 1983$, and are generally analyzed as [F]ourteenth [A]mendment claims wherein the use of force is considered a potential deprivation of liberty without due process of law." (citation omitted)); Starstead v. City of Superior, 533 F. Supp. 1365, 1368 (W.D. Wis., 1982) ("[W]hile the alleged facts do not appear sufficient to sustain a cause of action arising out of the Eighth Amendment ... they are sufficient to sustain a finding of a Fourteenth Amendment violation." (citation omitted)).
} 
Fourteenth Amendment offers an important point of comparison, we do not contend that this time period was ideal by any means. To be sure, substantive due process and fundamental rights analyses often reflect a form of constitutional individualism not unlike the Fourth Amendment context. Nevertheless, these data provide a glimpse into how courts approached these issues before Graham mandated that police violence cases would solely be addressed by the Fourth Amendment and "objective reasonableness." By largely rejecting the premise that the Fourteenth Amendment might apply to excessive force claims through various means, the courts after Graham have clearly demarcated the permissible bounds of a police excessive force claim as solely being within the terrain of the Fourth Amendment. ${ }^{119}$

\section{Foreclosing Equal Protection and Propagating Colorblindness}

Specific discussion of the Equal Protection Clause arose in 13 of the 250 cases $(5.2 \%)$ sampled post-Graham. This means that, after Graham, explicit involvement of equal protection claims in this area of constitutional law is rare. ${ }^{120}$ Moreover, even if litigants did raise the claim, it was most often rejected. Of the $5.2 \%$ of cases where there was a specific discussion of the Equal Protection Clause, 12 out of $13(92.3 \%)$ of the claims were rejected in some way by the court. ${ }^{121}$ Further, not all of these equal protection claims were "about race," meaning that while an equal protection claim was being made, it may have been in furtherance of a claim based on another protected class or may have been a claim included without any actual support. Of the 13 cases discussing equal protection, only $6(46.2 \%)$ of these equal protection claims were specifically equal protection claims about race.

\section{a. Equal protection claims about race}

Five of the six cases that made explicit equal protection claims about race were ultimately rejected. ${ }^{122}$ Reasons why these claims were not accepted include:

\footnotetext{
119 See supra Section III.B.2.a.

120 While equal protection claims were not exactly common before Graham (10.4\%), the point here is to show the rarity of equal protection after Graham regardless of how often these claims were made pre-Graham. By increasing the prominence of the Fourth Amendment, the Court impeded the viability of the Equal Protection Clause as part of the Fourteenth Amendment.

121 This means that the plaintiff did not necessarily win, but the court did not outright reject the claim at that stage.

122 See Lockett v. New Orleans City, 607 F.3d 992 (5th Cir. 2010); McElroy v. City of Birmingham, 903 F. Supp. 2d 1228 (N.D. Ala. 2012); Pryor v. City of Clearlake, 877 F. Supp. $2 d 929$ (N.D. Cal. 2012); Loharsingh v. City \& Cty. of San Francisco, 696 F. Supp. 2d 1080 (N.D. Cal. 2010); Jackson v. City of Pittsburgh, 688 F. Supp. 2d 379 (W.D. Pa. 2010).
} 
- After being assaulted during a traffic stop, the plaintiff's equal protection claim failed because "the officers did not make any sort of racist remarks"; 123

- When a mentally ill, African-American man was shot with a stun gun and brought suit under the Fourth Amendment and Equal Protection Clause, the court found that his "equal protection claim warrant[ed] summary adjudication in favor of Defendants because he... presented no evidence that similarly situated individuals were treated differently or that Defendants pursued a course of action because of his race or mental illness"; 124

- After an African-American man was fatally shot in his home, his estate brought suit, including an Equal Protection Clause claim. However, the court found that the plaintiff needed to show that the officer, under the same or similar conditions, did not use force against white people in the same way; ${ }^{125}$

- An African-American man brought suit for excessive force with an equal protection claim. The court noted that his claimed failed because "none of the officers made any derogatory racial remarks to Plaintiff." 26

Just one case included a race-based equal protection claim that a court accepted (to a degree). ${ }^{127}$ This case represents less than $1 \%$ of all of the postGraham police violence cases surveyed. Put differently, in only one sampled case did the plaintiff actually try to mobilize the Equal Protection Clause to argue for a racialized component of the use of excessive force in the context of a police interaction and have any success at all by surviving summary judgment. ${ }^{128}$

In this case, Hardy v. Emery, from the District Court of Maine, three African-American women brought suit regarding an altercation with a police officer in which one of the women-Andrea Hardy-sustained injuries when handcuffed. ${ }^{129}$ While handcuffing Hardy, the officer called another woman nearby-Quiana Harvey-a "nigger bitch" and other racist terms. ${ }^{130}$ In response, the court actually held that this kind of language - along with the

123 Jackson, 688 F. Supp. 2d at 395.

124 Pryor, 877 F. Supp. 2d at 935, 950.

125 McElroy, 903 F. Supp. 2d at 1231, 1254.

126 Loharsingh,696 F. Supp. at 1106; see also the fifth case, Lockett, 607 F.3d at 1002 ("We conclude that he has not demonstrated facts sufficient to demonstrate a conspiracy to deprive him of equal protection and the required act in furtherance of the conspiracy that caused injury or deprivation of any right.").

127 Hardy v. Emery, 241 F. Supp. 2d 38 (2003).

128 Id. at 49-50 (survived summary judgment).

129 Id. at $42-43$.

130 Id. at 43. 
officer's excessive actions - was sufficient for the plaintiffs' case to survive summary judgment. ${ }^{131}$

The constitutional terrain exemplified by Hardy serves as an imperfect example of where constitutional thought on police violence could go, from one restricted by the Fourth Amendment alone to one in which equal protection can potentially provide a deeper, group-based protection that recognizes the racialized dimensions of police violence. Procedurally, this may look as it did in this case, with a plaintiff bringing an excessive force claim under the Fourth Amendment paired with an equal protection claim, the combination of which could actually contemplate the fact that the force incident is intertwined with harm to a protected class. But, as can be seen in these data, this is exceedingly rare in the current constitutional moment.

Finally, in looking at both the unsuccessful and (relatively) successful equal protection claims, what we see is some kind of requirement for overt racist behavior, such as language used by the officer in Hardy. The issue is that this case featured a situation where evidence clearly demonstrated racial animus coinciding with force. The problem with this is it remains within the bounds of uncovering the smoking gun of explicit racist intent and is, thereby, another doctrinal hurdle as it stays within the individualized "bad apple" calculus and not the structural one we contend is necessary for comprehending the racialized phenomenon that is police violence.

\section{b. Colorblindness}

Our finding that only $17.2 \%$ of cases after Graham discuss the race of the plaintiff(s) or victim(s) and only $2.8 \%$ discuss the race of the officer(s) highlights the deracialized nature of excessive force cases. There is a praxis of constitutional colorblindness evinced by how rarely race is discussed. While $15.6 \%$ of pre-Graham cases discussed race of victims $(6.0 \%$ mention the race of the officer), the post-Graham numbers are incredibly low, such that we still see the further entrenchment of deracialization in excessive force claims that often have race at their center.

By deracializing police use of force cases, the Court has effectively stripped the excessive force inquiry of its racialized component, which is a form of institutional colorblindness that ultimately perpetuates structural violence on communities of color by failing to acknowledge racially disparate results and the need for race-sensitive remedies. It is important to note how hampering equal protection and supporting colorblindness helps to maintain status quo racial inequalities. The discourse of colorblindness and the jurisprudential obstruction of equal protection claims both serve to create a socio-legal climate that bars access to substantive remedies for group-based

131 Id. at $48-49$. 
harm while simultaneously mythologizing formal equality in a purportedly post-civil rights, post-racial moment.

In sum, these data draw attention to the rather significant shift ushered in by the Court's holding in Graham, which made the Fourth Amendment the primary - if not sole - vehicle for constitutionally cognizable excessive force claims. The Court's holdings on the Fourth Amendment and police violence have limited the excessive force doctrinal discussion, such that the Equal Protection Clause is viewed as having basically no place in excessive force jurisprudence. ${ }^{132}$ Thereby, the Court has been able to build a firewall against more critical, structural engagements with the Fourteenth Amendment and the Equal Protection Clause by valorizing the Fourth Amendment. Hence, the dominant narrative has become that excessive violence by the police is simply a matter of rogue or poorly trained individual officers and not a function of the racial injustices that occur throughout the criminal justice system. It is only from this standpoint that it becomes possible to think that equal protection does not apply.

\section{CONCLUSION: GRAHAM, MCCLESKEY, AND EQUAL PROTECTION}

We have argued that the primary constitutional mechanism used to protect citizens from excessive use of force by the police - the Fourth Amendment, as interpreted by Graham - actually produces racialized police violence by failing to engage the racialized group dynamics that underlie police violence in communities of color. ${ }^{133}$ The doctrinal insistence that excessive force exists as an isolated and individual dynamic apart from broader racial inequalities renders the Fourth Amendment a relatively futile constitutional terrain from which to adjudicate these matters, allowing police excessive force to fester and reproduce without any check from the judiciary. The Fourth Amendment, as interpreted post-Graham, simply operates at the wrong level; its individualist nature cannot address a fundamentally structural problem. For this reason, the existing jurisprudence does more harm than good by standing as a proxy for protection and remediation while ultimately providing little to communities of color.

Recognizing the futility of the Fourth Amendment is just the beginning of understanding the persistent problem of excessive force by the police. ${ }^{134}$ A full social, legal, political and ethical engagement with police brutality and

132 See supra notes 81, 120.

133 See generally ALEXANDER, supra note 80; BUTLER, supra note 7.

134 See also ZIMRING, supra note 3, at 219 ("[T] he main arena for the radical changes necessary to save many hundreds of civilian lives in the United States each year is the local police department, not the federal courts or Congress, not state government, not local mayors or city councils, not even the hearts and minds of the police officers on the streets."). 
excessive force requires interventions at multiple levels beyond Supreme Court decisions. But the issues this Essay explores and the empirical findings herein are consequential in that they highlight how constitutional framings can be a legal determinant for injustice on the ground and the health disparities that often result from the injuries that stem from these violent encounters. Thus, we hope that these data can be the beginning of a broader conversation concerning police violence as a social and legal determinant of health and how police reform can improve minority health outcomes. ${ }^{135}$

Throughout this Essay, we have suggested that the Fourteenth Amendment and its greater conceptual sensitivity to and awareness of group dynamics (as opposed to the Fourth Amendment's one-dimensional individual rights framework) might be a more appropriate vehicle through which to adjudicate matters concerning excessive police force. While other scholars have suggested that aspects of the Fourteenth Amendment might be more appropriate than the Fourth Amendment in examining criminal procedure matters such as "stop and frisk," 136 our empirical contribution is to demonstrate (1) the indeterminacy of the constitutional standard before Graham (where the Fourth Amendment did not play a prominent role in shaping excessive force doctrine) and (2) the radical and exclusive shift toward individualism facilitated by Graham. We contend that a more groupconscious framework aligned with the Fourteenth Amendment might be more appropriate in both remedying individual violations and creating the conditions for reform. Our hope is that this Essay will stimulate a conversation that can produce models that draw upon Fourteenth Amendment sensibilities that highlight the role of racial inequality and structural racism in precipitating excessive force by the police.

Yet, we also understand how the current jurisprudence surrounding the Fourteenth Amendment, and specifically equal protection, is not unproblematic. Namely, the existing emphasis in equal protection doctrine on individual discriminatory intent instead of disparate impact or group harm-arising from Washington v. Davis ${ }^{137}$ and exemplified by McCleskey

135 For a discussion of the health impacts of police violence, see Sirry Alang et al., Police Brutality and Black Health: Setting the Agenda for Public Health Scholars, 107 AM. J. PuB. HeAlth 662 (2017).

136 See, e.g., Brando Simeo Starkey, A Failure of the Fourth Amendment \& Equal Protection's Promise: How the Equal Protection Clause Can Change Discriminatory Stop and Frisk Policies, 18 MiCH. J. RACE \& L. 131, 136 (2012) ("The answer must be the Equal Protection Clause. The Equal Protection Clause of the Fourteenth Amendment, however, has been shredded.").

137426 U.S. 229 (1976). The intent doctrine creates an extremely truncated paradigm of how race and racism function in the present. For a discussion of its doctrinal evaluation, see Ian Haney-López, Intentional Blindness, 87 N.Y.U. L. REV. 1779 (2012). 
v. Kemp ${ }^{138}$ - prevents the effective remediation of racialized phenomena like police violence. To be sure, Graham's positioning of police excessive force as an individualistic matter is troublesome unto itself. Yet, there is an interaction effect above and beyond jurisprudential silos of the Fourth and Fourteenth Amendments when we read Graham alongside the individualist, intent-driven equal protection cases.

As they currently stand, the individualism embedded in Graham, Davis, and $M c C l e s k e y$ creates a doctrinal triad that precludes any kind of structural analysis of race and disparate impact, in police excessive force cases and beyond. Thus, the problem lies in the Court's conceptualization of race and racism as well as the diminished role of social science evidence in helping us understand patterns and mechanisms of discrimination. We must be attentive to how the Court established its approach to police excessive force in Graham as being within the sole domain of the individualist Fourth Amendment and "objective reasonableness" at the same post-civil rights moment ${ }^{139}$ it was revising how race and equal protection were to be addressed with Davis and McCleskey. ${ }^{140}$ This suggests a deeper ideological and political shift in how the Court thinks about race, racism, and state culpability.

Finally, it must be noted that, while constitutional law can seem lofty and abstract, it has real, material consequences that implicate everyday interactions between police and citizens. Police excessive force is a life-ordeath area of the law, dictated by the constitutional standards discussed in this Essay and materialized through the everyday interpretations of that law by police when they engage various communities. Graham and the contemporary constitutional law framework for police violence is part of the web of law, custom, and culture that enables police violence to remain an ingrained and routinized form of structural harm that communities of color are subjected to. Specifically, flawed constitutional law is an important determinant of health. ${ }^{141}$ By enabling normalized police violence and framing it as a series of disconnected individual disputes, constitutional law is liable

\footnotetext{
138481 U.S. 279 (1987).

139 For a discussion of post-civil rights racial backlash and its impact on the federal courts, see Ian F. Haney López, “A Nation of Minorities": Race, Ethnicity, and Reactionary Colorblindness, 59 STAN. L. REV. 985 (2007).

${ }^{140}$ In a genealogy of these decisions, an ideological pattern emerges: Graham was decided just two years after McCleskey. Chief Justice William Rehnquist-joined by Justice Sandra Day O'Connordelivered the opinion in Graham (1989); joined Justice Lewis Powell in the opinion in McCleskey (1987); joined Justice O'Connor's dissent in Garner (1985); and joined Justice Byron White in Washington v. Davis (1976).

141 See Osagie K. Obasogie \& Zachary Newman, Police Violence, Use of Force Policies, and Public Health, 43 AM. J. L. \& MED. 279 (2017) (contending that use of force policies are an important site in disrupting police violence because they are the main domain for police departments to articulate and reify the constitutional law standards, and that this process has profound implications for public health).
} 
for the broken bodies; loss of life and premature death; stress, anxiety, and depression; and community fragmentation that results from police excessive force. ${ }^{142}$ Thus, defective constitutional law-including the futile Fourth Amendment - combined with use of force policies developed by police departments that implement it, enables the violence done to individuals, communities, and public health.

In sum, the constitutional matrix surrounding racialized police violence - which includes the Court's conceptions of race and racism as well as Fourth Amendment jurisprudence - actively produces and perpetuates this violence by avoiding the structural nature of this problem and permitting police excessive force and killings to persist despite social movement and media attention. In order to address police violence - and all of the harms it creates-we must simultaneously critique Davis and McCleskey, while critically attending to Graham to render these constitutional individualisms an unsustainable terrain from which to address such deeply racialized problems.

142 See Alang et al., supra note 135. 